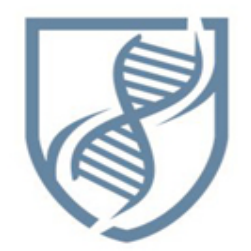

Journal of Bioscience and Applied Research
JBAAR

WWW.JBAAR.ORG

\title{
Preventive effect of wheat germ oil on methotrexate - induced liver injury and oxidative intestinal damage in mice
}

\author{
Hanan Saleh *, \\ Department of Zoology, Faculty of Science, Cairo University, Egypt. \\ *Corresponding author e.mail: hebead@sci.cu.edu.eg
}

\begin{abstract}
Methotrexate (MTX) is an anti-neoplastic drug that is widely used in the treatment of several diseases such as lymphoblastic leukemia, lymphoma, and autoimmune diseases, and has been concomitant with mild or severe liver and intestinal toxicity. One of the most attractive approaches to prevent toxicity of different organs involves the use of natural antioxidants. Thus, the present investigation was undertaken to study the possible protective effect of wheat germ oil (WGO) against single dose of methotrexate induced oxidative stress in hepatic and intestinal tissue. The oxidative stress was induced using single intraperitoneal injection of methotrexate (20 $\mathrm{mg} / \mathrm{kg}$ body weight), while the protecting effect was investigated by oral administration of WGO $(1400 \mathrm{mg} / \mathrm{kg}$ body weight), for six and three consecutive days before and after MTX injection respectively. MTX has revealed significant depletion of some oxidative biomarkers and an elevation in the activities of liver enzymes, Lactate dehydrogenase (LDH), intestinal malondialdehyde (MDA), lipid profile, and remarkable intestinal DNA damage, as well as abnormal architecture of mucosa. The present findings confirmed that WGO has significant preventive effect against liver injury and intestinal oxidative stress induced by MTX through improving the liver enzymes levels, enhancing the intestinal antioxidant defense status, reduction of lipid peroxidation level, and protection against different pathological changes. Taken together, it's then recommended to give WGO to individuals who are treated with MTX, although more pharmacological and molecular assays are necessary to elucidate its protective mechanisms.
\end{abstract}

Keywords: Methotrexate; Wheat germ oil; small intestine; lipid profile; DNA damage.

\section{Introduction}

Methotrexate (MTX) is a folate antagonist which is used not only as an anti-tumor drug but also considered as a keystone treatment of rheumatoid arthritis (Toquet et al. 2016). It is also widely used in the treatment of several diseases such as psoriasis, dermatomyositis, sarcoidosis and neoplastic diseases (Toquet et al. 2016). Therapeutic effect of MTX has been connected with mild or severe liver toxicity, including progressive hepatic fibrosis and cirrhosis (Tobias et al. 1973). MTX toxicity may be related to the depletion of tissue folates, where MTX is similarly in its structure to folic acid substance and binds to the active sites on the enzyme dihydrofolate reductase, hence by competitive inhibition blocks the formation of folate coenzymes which needed in the biosynthesis of DNA and RNA (Barak et al. 1984). The conversion of MTX to its major extracellular metabolite, 7-hydoxymethotrexate, takes place in the liver, where it is oxidized by a soluble enzymatic system (Şener et al. 2006). MTX enters the cell via active transport across the reduced folate carrier and is effluxes from the cell by several of the ATP-binding cassette transporters (Tousson et al. 2014). According to Aarsaether et al. (1988), MTX may be related to fat accumulation in the liver through decrease intracellular choline. Choline deficiency by MTX induces fatty accumulation in the liver and reduction in circulating phospholipids, triacylglycerol, and apolipoproteins. Moreover, MTX treatment may cause an elevation in the levels of cholesterol, triglyceride and low density lipoprotein-cholesterol LDL-C compared to the control (Georgiadis et al. 2006). 
Intestinal toxicity is one of the most serious side effects in the treatment with MTX. Where, MTX causes gastrointestinal toxicity such as diarrhea, nausea and decreased nutrient absorption (Miyazono et al. 2004). The mechanism of toxicity of MTX has attributed to the inhibition of dihydrofolate reductase which in turn inhibit the proliferation in the intestinal crypts which caused deterioration in the barrier function of the mucosa against intravascular bacteria resulting bacterial translocation and the occurrence of inflammation, with cellular infiltrates (Genestier et al. 2000).

Reactive Oxygen Species (ROS) production is playing an important role in the initiation and progress of tissue injury (Miyazono et al. 2004). ROS are implicated in the pathogenesis of the MTX-induced gastrointestinal mucosal injury. Where, inflammatory cells like macrophages, neutrophils, and monocytes produce ROS to react with bacteria. Nevertheless, they also react with lipids, proteins, and nucleic acids because of their high reactivity, causing tissue injury (Şener et al. 2006). However, Johovic et al. (2003) mentioned that MTX can decrease the availability of $\mathrm{NADPH}$ in cells by inhibiting the pentose cycle enzymes. Consequently, the failure in the antioxidant defense system may result in increased sensitivity of cells to ROS related injury. MTX-mediated tissue damage through elevation of lipid peroxidation (MDA) and LDH concentration in the small intestine (Şener et al. 2006). On the other hand, Huang et al. (2005) demonstrated that MTX- induced apoptosis in the small intestine which is dependent on ROS dependent and occurs through mitochondria-mediated pathway. Intestinal mucosal damage caused by chemotherapy has been massively documented. MTX causes acute injury to the intestinal epithelium characterized by reduced mitoses in the crypts and shortened villi. Also, MTX induced severe loss of villi, a decreased number of crypt cells, cellular edema. Therefore, it is important to minimize the side effect of MTX chemotherapy treatment, by reducing the mucosal damage and stimulating the tissue repairing system (Gao et al. 2002).

Wheat germ oil (WGO) is extracted from wheat germ and is known to be the natural source richest in tocopherol. WGO was described as anti-inflammatory and natural antioxidant because it has a high content of vitamin E. Also, it induces the tocopherol-mediated redox system and inhibits the synthesis of eicosanoid, which activates the lipid peroxidation process (Paranich et al. 2000). WGO also contains fat-soluble carotenoids such as lutein, zeaxanthin, and beta-carotene which have a powerful antioxidant effect. It was reported that WGO has a valuable source of essential fatty acids which cannot be synthesized in the body, including linoleic acid and linolenic acid, and have a chief role in the metabolism of the organism (Leenhardt et al. 2008).

Saturated, unsaturated fatty acids and phenolic compounds found in WGO have anti-inflammatory and antioxidant activities by decreasing the production of $\mathrm{O}_{2}$ and NADPH oxidase activity. Barakat et al. (2011) and Niu et al. (2013) reported that WGO acts as inhibitor of oxidation processes in body tissues and protects cells against the effects of free radicals, In addition, WGO defends components in the cell, nucleus, and DNA from damaging free radicals. That may rationalize the induction of chromosomal aberration, micronucleus (MN) test, and comet assay and gene mutation test by MTX in vivo leading to genetic damage (Sekhar et al. 2014). In this study, WGO was selected and tested for its modulatory activity on the DNA damage exerted by $20 \mathrm{mg} / \mathrm{kg}$ of MTX.

The aim of this study was to investigate the role of wheat germ oil to prevent the severe side effects of MTXinduced liver and intestinal injury through biochemical, and histological analysis.

\section{Material and Methods}

\section{Chemicals and Reagents}

Methotrexate (MYLAN- France) $(50 \mathrm{mg} / 2 \mathrm{~mL})$ vial for injection. Wheat germ oil (99\% purity) was purchased from Sigma-Aldrich (St. Louis, MO, USA). Kits for all biochemical parameters were purchased from Biodiagnostic Company (Giza, Egypt).

\section{Ethical Consideration}

Experimental protocols and procedures used in this study were approved by the Cairo University, Faculty of Science, Institutional Animal Care and Use Committee (IACUC) (Egypt) (CUFS/F/21/15). All the experimental procedures were carried out in accordance with international guidelines for the care and use of laboratory animals.

\section{Experimental Animals}

The experimental animals used in this study were male C57BL/6 mice weighing between 22-25 grams. The animals were obtained from the National Research Center (NRC, Dokki, Giza). Animals were grouped and housed in polyacrylic cages (six animals per cage) in the wellventilated animal house of the Department of Zoology, Faculty of Science, Cairo University. Animals were given food and water ad libitum. Mice were maintained in a friendly environment with a $12 \mathrm{~h} / 12 \mathrm{~h}$ light-dark cycle at room temperature $\left(22^{\circ} \mathrm{C}-25^{\circ} \mathrm{C}\right)$. Mice were acclimatized to laboratory conditions for 7 days before beginning of the experiment.

\section{Experimental Design}

Thirty two male C57BL/6 mice were divided into 4 groups randomly, each group includs 8 animals:

Control group: mice received the equivalent volumes of corn oil orally for 10 days and a single dose of saline intraperitoneally on the $7^{\text {th }}$ day.

MTX group: mice received corn oil orally for 10 days and a single dose of MTX (20 mg/kg) intraperitoneally on day 7 
of the experiment.

WGO group: mice received WGO $(1400 \mathrm{mg} / \mathrm{kg})$ orally for 10 days.

WGO + MTX: mice received WGO orally for 10 days and a single dose of MTX (20 mg/kg) intraperitoneally on day 7 of the experiment. The dose of MTX (20 mg/kg) was administered intraperitoneally and chosen as previously reported (Uraz et al. 2008; Tunal1-Akbay et al. 2010). WGO was given to the animals by oral gavage at dose (1400 mg/kg body weight), according to previous literature (Karabacak et al. 2011).

\section{Sample Preparation}

At the end of the 10th day, all the mice were sacrificed by decapitation; their blood samples were collected and centrifuged at 3000 r.p.m for minutes. Serum was stored at $-20 \circ \mathrm{C}$ until used for biochemical assays. The small intestinal tissues of all groups were removed and immediately divided into two parts: the first part was stored at $-80^{\circ} \mathrm{C}$ for biochemical studies, while the second part was suspended in $10 \%$ formal saline for fixation preparatory to histological processing.

\section{Small Intestine Homogenate Preparation}

Small intestine was homogenized (10\% w/v) in icecold $0.1 \mathrm{M}$ Tris-HCl buffer ( $\mathrm{pH} 7.4$ ). The homogenate was centrifuged at 3000 r.p.m for $15 \mathrm{~min}$. at $4^{\circ} \mathrm{C}$ and the resultant, the supernatant was used for the biochemical analyses.

\section{Histopathological Preparation}

Tissues of small intestine were fixed in $10 \%$ formal saline and embedded in paraffin wax blocks. Sections of 5 $\mu \mathrm{m}$ thickness were stained with hematoxylin and eosin (H\&E) and then examined under light microscope for determination of pathological changes (Meyer 1903).

\section{Biochemical Analysis}

Separated sera were used for the estimation of liver biomarkers according to the manufacturer protocol for determination of AST, ALT (Reitman 1957) and ALP (Tietz et al. 1983). LDH (Van der Heiden et al. 1994), total lipids (Zöllner et al. 1962), triglycerides (Stein et al. 1960), serum total cholesterol, high-density lipoprotein (HDL) (Tietz et al. 1995) and total antioxidant capacity (TAC) (Koracevic et al. 2001) were determined according to the manufacturer's instructions using Spectrum Diagnostics and Bio-diagnostic kits (Giza, Egypt). The concentration of LDL Cholesterol can be calculated according to Friedewaldes formula (Friedewald et al. 1972). LDL Cholesterol $(\mathrm{mg} / \mathrm{dl}) .=$ Total cholesterol $-($ triglycerides $/ 5)$ - HDL Cholesterol. Very low density lipoprotein (VLDL) was calculated from this formula: VLDL=Triglycerides/5. Intestinal Lipid Peroxidation was measured by the formation of Malondialdehyde (MDA) (Ohkawa et al. 1979), intestinal reduced glutathione (GSH) (Beutler et al.
1963), glutathione-S-transferase (GST) (Habig et al. 1974), intestinal catalase (CAT) (Aebi 1984), and intestinal superoxide dismutase (SOD) (Nishikimi et al. 1972) were determined using Bio-diagnostic assay kits according to the manufacturer's instructions (Giza, Egypt).

\section{DNA-Ladder fragmentation}

According to the standard protocol described by (Sambrook et al. 1989), the intestinal tissues were minced and lysed in $600 \mu \mathrm{l}$ lysis buffer containing $10 \mathrm{mM}$ Tris- $\mathrm{HCl}$, $\mathrm{pH}$ 7.4, 10 mM EDTA and 0.2 \% triton-100x for $20 \mathrm{~min}$ on ice before centrifugation, then incubated with $50 \mu \mathrm{g} / \mathrm{ml}$ proteinase $\mathrm{K}$ at $56^{\circ} \mathrm{C}$ overnight, and then centrifuged at $10,000 \mathrm{rpm}$ for $30 \mathrm{~min}$, and precipitated in 0.1 volume of 5 $\mathrm{M} \mathrm{NaCl}$. Soluble DNA in the resulting supernatant was precipitated with 600 isopropyl alcohol at $0^{\circ} \mathrm{C}$ overnight. The DNA pellet was then rinsed with $70 \%$ ethanol, mixed with TE buffer, and incubated with $100 \mathrm{~g} / \mathrm{ml}$ RNase A at 56 ${ }^{\circ} \mathrm{C}$ for 1 hour. Electrophoresis was carried out on a $1.5 \%$ agarose gel containing ethidium bromide. The gel was examined and photographed under UV light to visualize DNA fragmentation (laddering), characteristic of apoptosis.

\section{Statistical Analysis}

Data were analyzed using GraphPad software (Version 5.01, San Diago, USA). All the results were expressed as means \pm SEM of eight mice in each group. Treated groups are compared with control and MTX group by using Unpaired Student's t-test $* \mathrm{P}<0.05$, $* * \mathrm{P}<0.01$ vs control group, \#P < 0.05; \#\#P < 0.01 vs MTX.

\section{Results}

\section{Biochemical Analysis}

A significant increase $(P<0.01)$ in the activity of the biomarkers of liver injury, AST, ALT, ALP, and LDH was noticed in MTX-treated mice compared to the control group (Fig. 1). Pretreatment with WGO prevents the elevation in the activities of the hepatic enzymes. The percentage of decrease in the liver marker enzymes at the WGO + MTX was (-39.28 for AST; -49.49 for ALT; 40.69 for ALP and $-34.40 \%$ for LDH) compared to MTX group. Particularly, Non-significant difference was observed between control and WGO groups. Table (1) summarizes the data obtained on the effect of methotrexate and the protective effect of wheat germ oil on serum levels of the liver profile. Briefly, MTX caused a significant increase $(P<0.01)$ in total lipids, triglycerides $(P<0.05)$, total cholesterol, LDL-cholesterol, and VLDL-cholesterol when compared to the control group. While caused a significant reduction $(P<0.01)$ in serum HDL-cholesterol when compared to the control group. Contrary, administration of wheat germ oil before and after treatment with methotrexate decreased the levels of total lipids $(P<$ $0.01)$, triglycerides $(P<0.05)$, total cholesterol $(P<0.01)$, LDL-cholesterol and VLDL-cholesterol $(P<0.05)(-83.88$, $-33.08,-73.70,-302.74,-24.12 \%)$ respectively relative to the MTX group. While the concentration of HDL- 

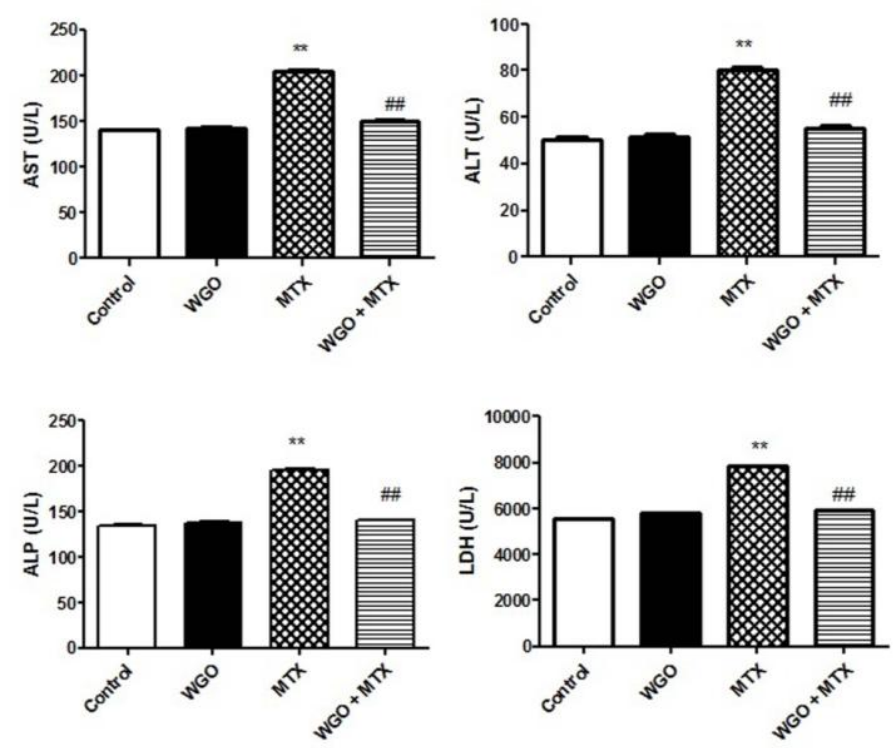

Fig. 1 Effect of wheat germ oil on biochemical parameters of MTX-induced liver injury

Treated groups are compared with control and MTX groups by using Unpaired Student's $t$-test values are means \pm SE. $* P<$ $0.05 \&{ }^{* *} P<0.01$ vs control group and ${ }^{\#} P<0.05 \&{ }^{\# \#} P<0.01$ vs MTX.

Table 1. Effect of wheat germ oil on MTX-induced changes in serum lipid profile

\begin{tabular}{|c|c|c|c|c|c|}
\hline Parameters & Control & WGO & MTX & WGO + MTX & $\begin{array}{c}\% \\
\text { improvement }\end{array}$ \\
\hline $\begin{array}{l}\text { Total Lipids } \\
\text { (mg/dL) }\end{array}$ & $958.61 \pm 20.06$ & $423.4 \pm 47.67$ & $1351.00 \pm 78.02^{* *}$ & $546.83 \pm 25.94^{\# \#}$ & $(-83.88)$ \\
\hline $\begin{array}{l}\text { Triglycerides } \\
\text { (mg/dL) }\end{array}$ & $110.91 \pm 1.79$ & $110.71 \pm 2.46$ & $145.01 \pm 1.89^{*}$ & $108.32 \pm 3.39^{\#}$ & $(-33.08)$ \\
\hline $\begin{array}{c}\text { Total } \\
\text { Cholesterol } \\
(\mathbf{m g} / \mathbf{d L})\end{array}$ & $122.63 \pm 3.15$ & $105.01 \pm 1.48$ & $191.11 \pm 1.26^{* *}$ & $100.73 \pm 8.02^{\# \#}$ & $(-73.70)$ \\
\hline $\begin{array}{l}\text { HDL-cholesterol } \\
\text { (mg/dL) }\end{array}$ & $66.94 \pm 0.87$ & $73.86 \pm 2.87$ & $43.53 \pm 0.57^{* *}$ & $60.21 \pm 0.68^{\# \#}$ & (24.91) \\
\hline $\begin{array}{l}\text { LDL-cholesterol } \\
\text { (mg/dL) }\end{array}$ & $33.50 \pm 1.36$ & $11.99 \pm 1.45$ & $120.60 \pm 1.96^{* *}$ & $19.18 \pm 1.33^{\# \#}$ & $(-302.74)$ \\
\hline $\begin{array}{l}\text { VLDL- } \\
\text { cholesterol } \\
\text { (mg/dL) }\end{array}$ & $22.18 \pm 0.99$ & $22.15 \pm 0.55$ & $27.01 \pm 1.33^{*}$ & $21.66 \pm 1.35^{\#}$ & $(-24.12)$ \\
\hline
\end{tabular}

cholesterol was increased significantly $(P<0.01)$ with highly \% of improvement (24.91\%) when compared with MTX group.

\section{Intestinal Histopathological examination}

The small intestine of the control group (Fig. 2, A) showing normal mucosal and submucosal layers. Small Intestine of mice received wheat germ oil (WGO) showing activated mucous cells in the mucosal and glandular epithelium (B). The small intestine of MTX group showed cystic and dilatation of some intestinal glands (C). While the administration of wheat germ oil ameliorates the architecture of the small intestine of mice subjected to MTX (WGO + MTX (D).

Total Antioxidant Capacity and Intestinal Oxidative Stress Markers

The current study revealed that MDA level was significantly $(P<0.01)$ increased in MTX-treated mice when compared to control group. While, a significant decreased $(P<0.01)$ in levels of GSH, CAT, GST, SOD and TAC in MTX group when compared to the control group. In contrast, the level of MDA was decreased significantly in WGO + MTX group (-18.18\%) when compared to the MTX-treated group. While, the concentrations of GSH, CAT, GST, SOD and TAC were 


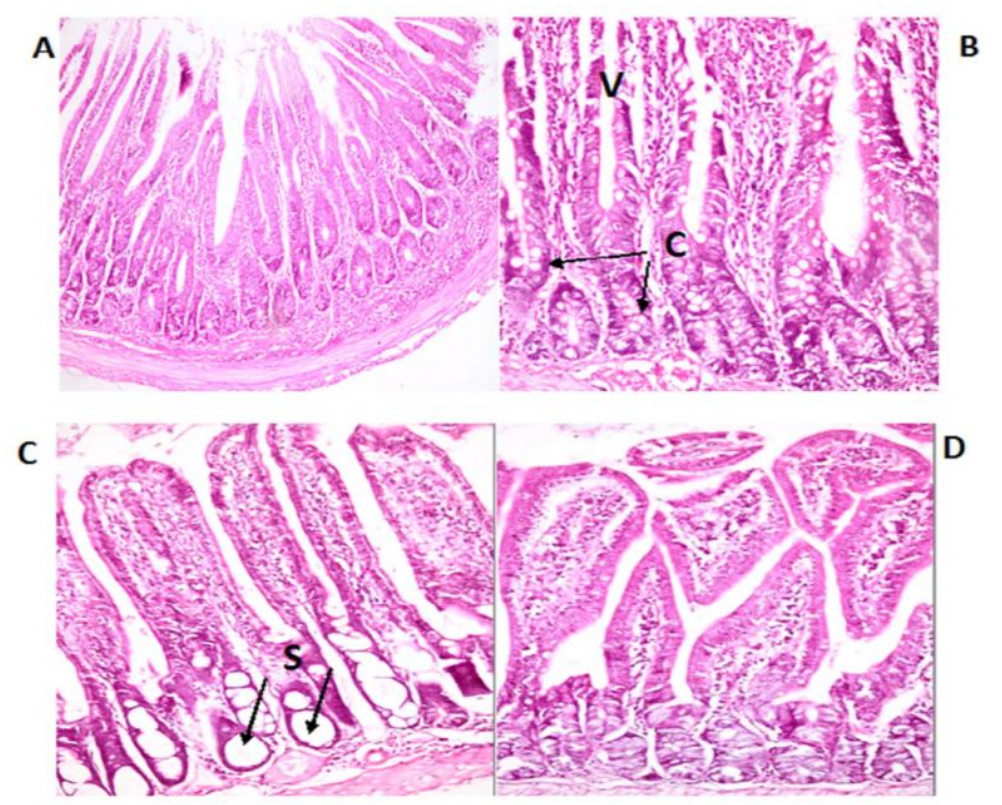

Fig. 2 Photomicrographs of intestinal tissues of mice stained with H\&E. The control group (A) showing the normal and healthy architecture of intestinal tissues including cylindrical glandular epithelium and the finger-like villi structure (V) (X200). The small intestine of WGO group (B) showing activated mucous cells in the mucosal and glandular epithelium (C). The small intestine of (MTX) group showing cystic (S) and dilatation of some intestinal glands (C). The small intestine of (WGO + MTX) group restored their normal architecture (D) (X 400).
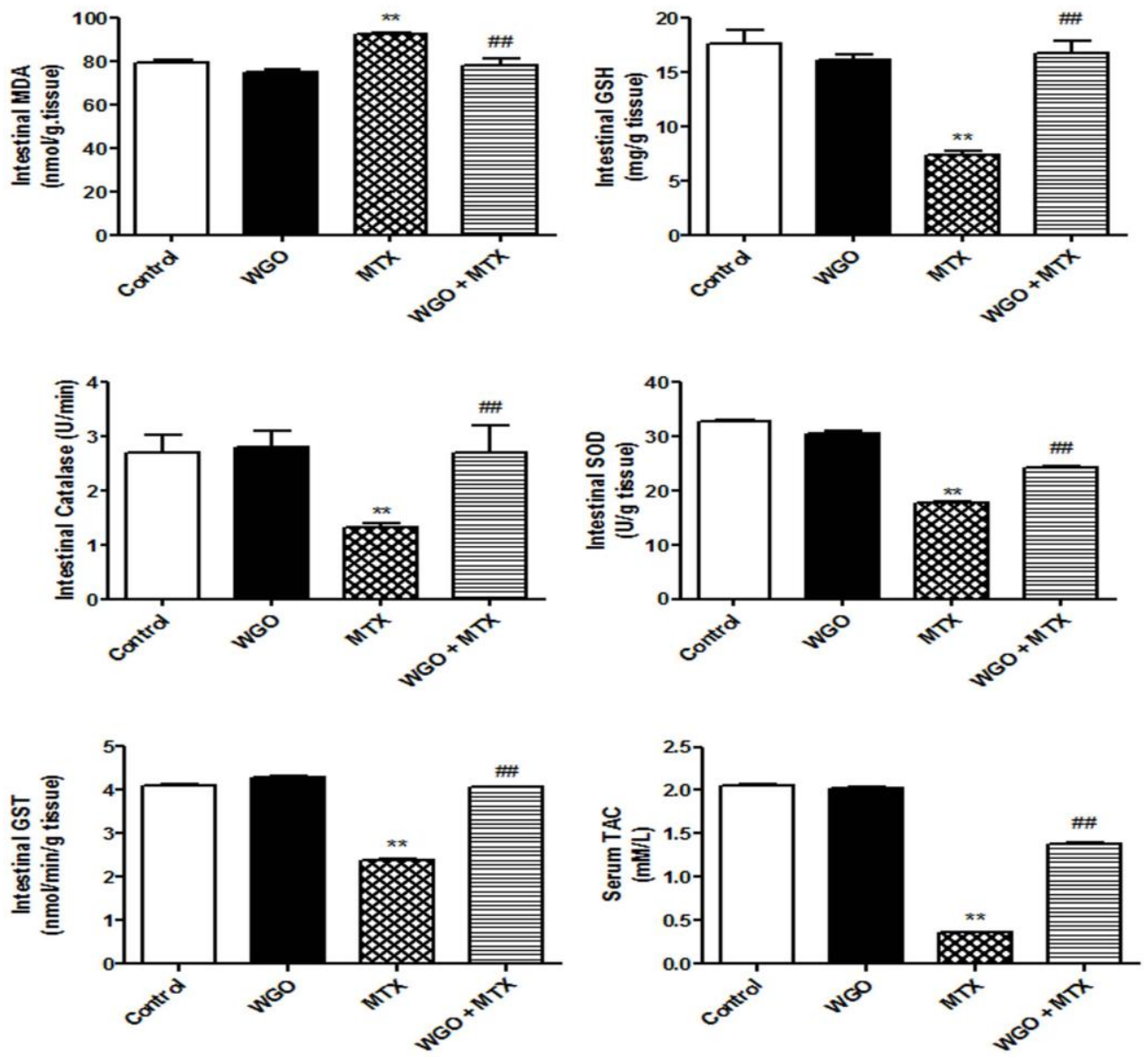

Fig.3 Effect of wheat germ oil on MTX-induced changes in antioxidant markers of the small intestine. Treated groups are compared with control and MTX groups by using Unpaired Student's $t$-test, values are means \pm SE. $* P<0.05 \&{ }^{* * P}<$ 0.01 vs control group and ${ }^{\#} P<0.05 \&{ }^{\#} P<0.01$ vs MTX. 
increased significantly $(P<0.01)$ (53.07, 50.92, 40.63, liver or interference with lipid deposition. The pathogenesis 20.09, 49.11\%, respectively) subsequent to the oral is multi-factorial, reflecting complex biosynthetic, administration of wheat germ oil before the MTX injection enzymatic and catabolic derangement in lipoprotein (Fig.3).

\section{Intestinal DNA fragmentation} metabolism. MTX caused Liver hepatotoxicity, including steatosis, cholestasis, fibrosis, and cirrhosis (Pal et al. 2008)

Low level of intestinal nuclear DNA fragmentation, was detected as slight smears in WGO - MTX group, compared to intact genomic DNA in WGO and control groups (Fig.4). However, high level of random DNA degradation was detected as highly dense smears in MTX treated group.

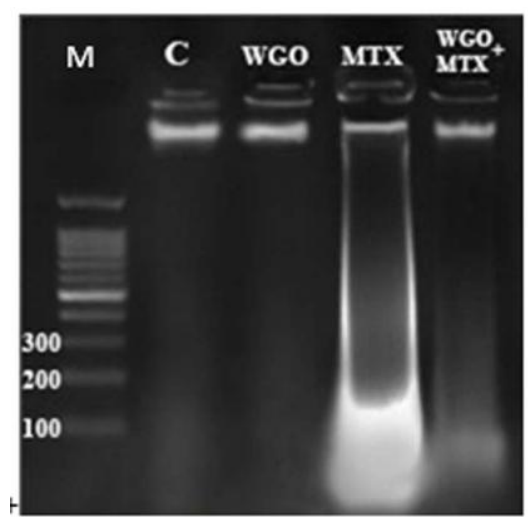
In the present study, total lipids, triglyceride, total cholesterol and LDL-cholesterol levels were significantly elevated in MTX treated mice. Whereas, HDL-cholesterol level was decreased significantly compared with control group, reflecting the worst effect of MTX on the liver. Administration of WGO could improve lipid profile of mice treated with MTX by its ability to reduce the absorption of triacylglycerol and cholesterol through the inhibition of the hydrolytic activity of pancreatic lipase and the reduction in triacylglycerol lipolysis (Borel et al. 1989). In addition, WGO is a valuable source of the high amount of unsaturated fatty acid and high amount of unsapounfible matter specially sterols cholesterol-lowering, (sterols), and essential fatty acids including lenoleic acid and alpha linolic acid which stimulate fatty acid oxidation as well as octacosanol and natural vitamin E (Fontanel 2013).

Toxicity of the small intestine is one of the most serious side effects of MTX treatment. Intestinal mucosa was damaged structurally and functionally after chemotherapy in cancer and rheumatoid arthritis patients (Phelan et al. 1993). It was reported that MTX induced intestinal damage not only through increased production of

Fig. 4 Fragmentation assay of DNA extracted from intestinal tissues of mice. Lane M: DNA ladder (low molecular weight ranges from 100-1000), C: DNA of control group, WGO: WGO-treated mice, MTX-treated mice, WGO + MTX: WGO administration prior to and after MTX treated mice.

\section{Discussion}

Although MTX is an anti-inflammatory medication commonly used in the treatment of rheumatoid arthritis and other inflammatory diseases such as psoriasis and inflammatory bowel disease, MTX is linked with particularly adverse effects which require consideration (Coomes et al. 2011). The mechanism of the MTX toxicity is attributed to the conversion of MTX to its major extracellular metabolite, 7-hydroxymethotrexate, which takes place in the liver, where it is oxidized by a soluble enzymatic system. Inside cells, MTX is stored in a polyglutamated form. The presence of higher levels of polyglutamates causes a longer intracellular presence of the drug, and this has been suggested as a mechanism for MTX hepatotoxicity (Jahovic et al. 2003). Significant increase in the values of AST, ALT and ALP activities and LDH in MTX group in our study are in accordance with previous researchers who reported increased the activities of liver enzymes by a single dose of methotrexate that shows the damaging effect of MTX treatment on the liver.(Uraz et al. 2008; Vaghasiya et al. 2009; Tunal1-Akbay et al. 2010). The significant disorder faced in the drugs-induced hepatotoxicity is fatty accumulation in the liver, which progresses either due to excessive supply of lipids to the antioxidant defense system which linked with the development of several pathological processes (Şener, et al. 2006). Enterocolitis due to intestinal damage is one of the most frequent and severe side effects of MTX. The histological structure of intestinal mucosa in our study was reflected the severe pathological effect of methotrexate on the mucosa of the small intestine. Where, cystic dilatation of some intestinal glands, loss of goblet cells and epithelial desquamation occurred and similarly described in previous studies (Şener et al. 2006). The injured intestinal cells demonstrate the presence of oxidant stress, evidenced by enhanced lipid peroxidation as indicated by an increase in MDA level as shown in our study. In contrast, the present study showed the capability of WGO induces the tocopherol-mediated redox system and vitamin $\mathrm{C}$, in preventing the damage of small intestine by inhibiting lipid peroxidation and reducing the degree of oxidative stress induced by MTX.

ROS production in inflammatory diseases is responsible for the initiation and progression of tissue injury. The inflammatory cells produced ROS, to disinfect the bacteria, binding to cellular macromolecules, principally membrane lipids and polyunsaturated fatty acids causing lipid peroxidation and consequently tissue injury (Naik et al. 2007) and irreversible damage to cells and organelle contents. Increased levels of MDA as in our study, may be attributed to overproduction of reactive oxygen species or a deficiency of antioxidant defense which induced by MTX treatment (Miyazono et al. 2004).

$\mathrm{LDH}$ is an enzyme that exists in many tissues and organs when those tissues or organs are damaged, LDH is 
released into the blood from cells. Therefore, LDH leakage can be used as an indicator of cell damage and serious intestinal edema (Zhang et al. 2001). The accumulation of MDA and LDH as reported in our study could be a strong indicator of intestinal injury. On the other hand, lipid peroxidation MDA and LDH were markedly decreased by WGO administration which kept MDA and LDH at the near control level. This may be due to the presence of vitamin $\mathrm{E}$ which gives powerful antioxidant protection against tissue injury, in addition, to decreasing the leakage of LDH by reducing the production of ROS (Mehranjani et al. 2007).

GSH is an endogenous anti-oxidant, present within many cells of the body and protects the functional proteins of the cell against oxidative stress through the removal of free radicals such as $\mathrm{H}_{2} \mathrm{O}_{2}$, superoxide anions, and alkoxy radicals. Several investigators suggest that MTX-treatment diminishes GSH levels in many tissues by $70 \%$ causing a reduction in the effectiveness of the antioxidant enzyme defense system (Jahovic et al. 2004). Our results GSH level was significantly elevated in MTX group when treated with WGO. Wheat germ oil is unique dietary supplements, it is highly rich in the most biologically active forms of naturally occurring vitamin $\mathrm{E}$ and mixed tocopherols Vitamin $\mathrm{E}$ acts as an inhibitor of oxidative processes in body tissues, it is potent peroxyl radical scavenger that prevents the propagation of free radical damage in biological cell membranes (Singh et al. 2006).

SOD and CAT enzymes are the backbones of the antioxidant defense system. SOD is considered as the fastest enzyme-catalysed reaction that detoxifies $\mathrm{O}_{2}$ generated during MTX treatment, by converting it to $\mathrm{H}_{2} \mathrm{O}_{2}$ enzymes cascade. CAT is one of the most efficient enzymes largely contained in peroxisomes that catalysis the reduction of $\mathrm{H}_{2} \mathrm{O}_{2}$ and protects the cells from the propagation of ROS and hydroxyl radicals (Kruidenier et al. 2002).

GST is one of non-enzymatic antioxidant and splays a critical role in defense mechanisms against lipid peroxidation. Its role in tissue protection against $\mathrm{H}_{2} \mathrm{O}_{2}$ or oxidant toxicity is provided by their ability to attenuate lipid peroxidation by reducing the hydroperoxides (Sharma et al. 2004). The activities of SOD, CAT and GST were decreased significantly in the present study. Many studies also support the view that oxidative stress plays a role in MTX- induced small intestinal damage which probably due to the decrease in their synthesis or increase in the consumption (Ateşşahin et al. 2007). In this study, SOD, CAT, and GST activities were significantly elevated when treated with WGO. These results are in accordance with Liu et al. (2008) who mentioned that WGO is a source of simply vitamin $\mathrm{E}$ which protects cells against the effects of free radicals by inhibiting the oxidation processes which are potentially damage the tissues. In addition, WGO is richly in tocopherols. As is known, owing to it radical scavenging activity and is considered as strong antioxidant.

Plasma plays a vital role in preventing reactions with catalytic metal ions to produce more harmful species through scavenging long-lived ROS, such as the super oxide anion or hydrogen peroxide. Moreover, it gives more biologically relevant information than that obtained from measuring concentrations of individual antioxidants (Bartosz 2003). In our study, the significant reduction in total antioxidant capacity was reflected the MTX-induced oxidative stress. On the other hand, the intake of WGO resulted in a rapid increase in TAC. The obtained results are in agreement with who reported that WGO which contains the highest content of $\alpha$ - tocopherol, which around $60 \%$ of the total content (Piras et al. 2009). It could decrease the oxidative stress and increase the activities of antioxidant enzymes. So it protects the small intestine from damaged occur by MTX treatment

An appearance of the smeared pattern of genomic DNA on an agarose gel, evidenced DNA damage inductions and fragmentation by MTX, while the disappearance of such smear in WGO + MTX group indicates its ability to modulate MTX effects. These results are in agreement with Yuluğ et.al. (2013), who revealed that MTX induces gut mucosal apoptosis and oxidative DNA damage. These effects may be attributed to ROS generation, as indicated by significant elevation in lipid peroxidation marker (MDA), and depletion in the antioxidant defense systems, mainly GSH, SOD and GST by MTX treatment (Miyazono et al. 2004). Reactive oxygen species (ROS) can oxidize fatty acid of membrane phospholipids, peroxidized fatty acids can generate other free radicals, leading to more cell membrane and DNA damage, including DNA strand breaks, cross-linking, and adducts of the bases or sugars. Moreover, an effect of methotrexate administration is a cycling process of deoxyuracil monophosphate (dUMP) removal, reincorporation, and removal. This can lead to a progressive accumulation of DNA strand breaks (Bjelland et al. 2003) , all of which may explain MTX-induced DNA damage. Treatment with WGO, as an antioxidant, prior to administration of MTX, resulted in significant attenuation in all ROS measured parameters, and consequently, decreasing DNA fragmentation which is considered as one of the later steps in the apoptotic process.

In conclusion: The present study evidenced that MTX not only induced liver injury by the marked elevation in the liver enzymes and LDH but also caused an elevation in intestinal MDA and DNA damage. Severe depletion in the intestinal antioxidant status was followed by methotrexate treatment. The vital mechanism of WGO in preventing these damage through improving the liver function enzymes and the ability to scavenge a variety of free radical species that cause impairments of intestinal architecture and DNA fragmentation in mice intestinal cells.

\section{References}

Aarsaether N, Berge RK, Aarsland A, Svardal A, and Ueland PM. (1988). Effect of methotrexate on longchain fatty acid metabolism in liver of rats fed a standard or a defined, choline-deficient diet. Biochim Biophys Acta Lipids Lipid Metabol, 958: 70-80. 
Aebi H. (1984). Catalase in vitro. Meth Enzymol, 105: 121-26.

Ateşşahin A, Çeribaşı AO, and Yılmaz S. (2007). Lycopene, a Carotenoid, Attenuates Cyclosporine-Induced Renal Dysfunction and Oxidative Stress in Rats. Basic Clin Pharmacol Toxicol, 100: 372-76.

Barak A, Tuma D, and Beckenhauer H. (1984). Methotrexate hepatotoxicity. J Am Coll Nutr, 3: 93-96.

Barakat IA, Abbas OA, Ayad S, and Hassan AM. (2011). Evaluation of radioprotective effects of wheat germ oil in male rats. J Am Sci, 7: 664-73.

Bartosz G. (2003). Total antioxidant capacity. Advances in clinical chemistry, 37: 219-92.

Beutler E, Duron O, and Kelly BM. (1963). Improved method for the determination of blood glutathione. J Lab Clin Med, 61: 882-88.

Bjelland S, and Seeberg E. (2003). Mutagenicity, toxicity and repair of DNA base damage induced by oxidation. Mutation Research/Fundamental and Molecular Mechanisms of Mutagenesis, 531: 37-80.

Borel P, Lairon D, Senft M, Chautan M, and Lafont H. (1989). Wheat bran and wheat germ: effect on digestion and intestinal absorption of dietary lipids in the rat. The American journal of clinical nutrition, 49: 1192-202.

Coomes E, Chan ES, and Reiss AB. (2011). Methotrexate in atherogenesis and cholesterol metabolism. Cholesterol, 2011.

Fontanel D.(2013). Unsaponifiable matter in plant seed oils (Springer- Verlag Berlin Hridelberg ).

Friedewald WT, Levy RI, and Fredrickson DS. (1972). Estimation of the concentration of low-density lipoprotein cholesterol in plasma, without use of the preparative ultracentrifuge. Clinical chemistry, 18: 499502.

Gao F, Tomitori H, Igarashi K, and Horie T. (2002). Correlation between methotrexate-induced intestinal damage and decrease in polyamine content. Life sciences, 72: 669-76.

Genestier L, Paillot R, Quemeneur L, Izeradjene K, and Revillard J-P. (2000). Mechanisms of action of methotrexate. Immunopharmacology, 47: 247-57.

Georgiadis AN, Papavasiliou EC, Lourida ES, Alamanos Y, Kostara C, Tselepis AD, and Drosos AA. (2006). Atherogenic lipid profile is a feature characteristic of patients with early rheumatoid arthritis: effect of early treatment-a prospective, controlled study. Arthritis Res Ther, 8: R82.

Habig WH, Pabst MJ, and Jakoby WB. (1974). Glutathione S-transferases the first enzymatic step in mercapturic acid formation. J Biol Chem, 249: 7130-39.

Huang C, Hsu P, Hung Y, Liao Y, Liu C, Hour C, Kao M, Tsay G, Hung H, and Liu G. (2005). Ornithine decarboxylase prevents methotrexate-induced apoptosis by reducing intracellular reactive oxygen species production. Apoptosis, 10: 895-907.

Jahovic N, Çevik H, Şehirli AÖ, Yeğen BÇ, and Şener G. (2003). Melatonin prevents methotrexate-induced hepatorenal oxidative injury in rats. J Pineal Res, 34: 28287.
Jahovic N, Şener G, Çevik H, Ersoy Y, Arbak S, and Yeğen BÇ. (2004). Amelioration of methotrexate-induced enteritis by melatonin in rats. Cell Biochem Funct, 22: 169-78.

Karabacak M, Kanbur M, Eraslan G, and Sarıca ZS. (2011). The antioxidant effect of wheat germ oil on subchronic coumaphos exposure in mice. Ecotoxicol Environ Saf, 74: 2119-25.

Koracevic D, Koracevic G, Djordjevic V, Andrejevic S, and Cosic V. (2001). Method for the measurement of antioxidant activity in human fluids. J Clin Pathol, 54: 356-61.

Kruidenier La, and Verspaget H. (2002). Oxidative stress as a pathogenic factor in inflammatory bowel disease-radicals or ridiculous? Aliment Pharmacol Therapeut, 16: 1997-2015.

Leenhardt F, Fardet A, Lyan B, Gueux E, Rock E, Mazur A, Chanliaud E, Demigné C, and Rémésy C. (2008). Wheat germ supplementation of a low vitamin $\mathrm{E}$ diet in rats affords effective antioxidant protection in tissues. J Am Coll Nutr, 27: 222-28.

Liu D, Shi J, Ibarra AC, Kakuda Y, and Xue SJ. (2008). The scavenging capacity and synergistic effects of lycopene, vitamin $\mathrm{E}$, vitamin $\mathrm{C}$, and $\beta$-carotene mixtures on the DPPH free radical. LWT-Food Science and Technology, 41: 1344-49.

Mehranjani MS, Abnosi M, Naderi A, and Mahmodi M. (2007). Preventing effects of wheat germ oil on sex hormones, liver enzymes, lipids and proteins in rat serum following treatment with p-nonylphenol. J Biol Sci, 7: 1408-11.

Meyer A. (1903). An attempt at analysis of the neurotic constitution. The American Journal of Psychology, 14: 90-103.

Miyazono Y, Gao F, and Horie T. (2004). Oxidative stress contributes to methotrexate-induced small intestinal toxicity in rats. Scand J Gastroenterol, 39: 1119-27.

Naik SR, and Panda VS. (2007). Antioxidant and hepatoprotective effects of Ginkgo biloba phytosomes in carbon tetrachloride-induced liver injury in rodents. Liver Int, 27: 393-99.

Nishikimi M, Rao NA, and Yagi K. (1972). The occurrence of superoxide anion in the reaction of reduced phenazine methosulfate and molecular oxygen. Biochem Biophys Res Comm, 46: 849-54.

Niu L-Y, Jiang S-T, and Pan L-J. (2013). Preparation and evaluation of antioxidant activities of peptides obtained from defatted wheat germ by fermentation. Journal of food science and technology, 50: 53-61.

Ohkawa H, Ohishi N, and Yagi K. (1979). Assay for lipid peroxides in animal tissues by thiobarbituric acid reaction. Anal Biochem, 95: 351-58.

Pal R, Rana S, Vaiphei K, and Singh K. (2008). Isoniazid-rifampicin induced lipid changes in rats. Clin Chim Acta, 389: 55-60.

Paranich V, Cherevko O, Frolova N, and Paranich A. (2000). [The effect of wheat germ oil on the antioxidant 
system of animals]. Likars' ka sprava/Ministerstvo okhorony zdorov'ia Ukrainy: 40-44.

Phelan M, Taylor W, Van Heyningen C, Williams E, and Thompson R. (1993). Intestinal absorption in patients with rheumatoid arthritis treated with methotrexate. Clin Rheumatol, 12: 223-25.

Piras A, Rosa A, Falconieri D, Porcedda S, Dessì MA, and Marongiu B. (2009). Extraction of oil from wheat germ by supercritical CO2. Molecules, 14: 2573-81.

Reitman SaF, S. . (1957). A colorimetric method for the determination of serum glutamic oxalacetic and glutamic pyruvic transaminases. . Am. J. Clin. Pathol.,, 28: 56-63.

Sambrook J, and Russell David W.(1989). Molecular cloning: a laboratory manual. Vol. 3 (Cold spring harbor laboratory press).

Sekhar Singh Bhaludra C, Chari Murugulla A, Pullagummi C, and Rani Anupalli R. (2014). Anticancer Studies of Leucovorin against Methotrexate Induced Genotoxicity in Swiss Albino Mice. Lett Drug Des Discov, 11: 10-14.

Şener G, Ekşioğlu-Demiralp E, Cetiner M, Ercan F, Şirvancı S, Gedik N, and Yeğen B. (2006). L-Carnitine ameliorates methotrexate-induced oxidative organ injury and inhibits leukocyte death. Cell Biol Toxicol, 22: 47-60.

Şener G, Ekşioğlu-Demiralp E, Çetiner M, Ercan F, and Yeğen BÇ. (2006). $\beta$-glucan ameliorates methotrexateinduced oxidative organ injury via its antioxidant and immunomodulatory effects. Eur J Clin Pharmacol, 542: 170-78.

Sharma R, Yang Y, Sharma A, Awasthi S, and Awasthi YC. (2004). Antioxidant role of glutathione Stransferases: protection against oxidant toxicity and regulation of stress-mediated apoptosis. Antioxidants and Redox Signaling, 6: 289-300.

Singh DK, Li L, and Porter TD. (2006). Policosanol inhibits cholesterol synthesis in hepatoma cells by activation of AMP-kinase. J Pharmacol Exp Therapeut, 318: 1020-26.

Stein Y, and Shapiro B. (1960). Uptake and metabolism of triglycerides by the rat liver. J Lipid Res, 1: 326-31.

Tietz N, Burtis C, Duncan P, Ervin K, Petitclerc C, Rinker A, Shuey D, and Zygowicz E. (1983). A reference method for measurement of alkaline phosphatase activity in human serum. Clinical chemistry, 29: 751-61.
Tietz PS, Holman RT, Miller LJ, and LaRusso NF. (1995). Isolation and characterization of rat cholangiocyte vesicles enriched in apical or basolateral plasma membrane domains. Biochemistry, 34: 15436-43.

Tobias H, and Auerbach R. (1973). Hepatotoxicity of long-term methotrexate therapy for psoriasis. Arch Intern Med, 132: 391-96.

Toquet S, Nguyen Y, Sabbagh A, Djerada Z, Boulagnon C, and Bani-Sadr F. (2016). Severe apoptotic enteropathy caused by methotrexate treatment for rheumatoid arthritis. Joint Bone Spine, 83: 217-19.

Tousson E, Atteya Z, El-Atrash A, and Jeweely OI. (2014). Abrogation by Ginkgo Byloba Leaf Extract on Hepatic and Renal Toxicity Induced by Methotrexate in Rats. J Canc Treat Res, 2: 44-51.

Tunali-Akbay T, Sehirli O, Ercan F, and Sener G. (2010). Resveratrol protects against methotrexate-induced hepatic injury in rats. J Pharm Pharmaceut Sci, 13: 303-10.

Uraz S, Tahan V, Aygun C, Eren F, Unluguzel G, Yuksel M, Senturk O, Avsar E, Haklar G, and Celikel C. (2008). Role of ursodeoxycholic acid in prevention of methotrexate-induced liver toxicity. Dig Dis Sci, 53: 107177.

Vaghasiya J, Bhalodia Y, and Rathod S. (2009). Drug induced hepatotoxicity: effect of polyherbal formulation. Phcog Mag, 5: 232-39

Van der Heiden C, Bais R, Gerhardt W, Lorentz K, and Rosalki S. (1994). Approved recommendation on IFCC methods for the measurement of catalytic concentration of enzymes. Part 8. IFCC method for lactate dehydrogenase. Eur J Clin Chem Clin Biochem, 32: 639-55.

Yuluğ E, Türedi S, Alver A, Türedi S, and Kahraman C. (2013). Effects of resveratrol on methotrexate-induced testicular damage in rats. The Scientific World Journal, 2013:1-6

Zhang Y, Wu Y-X, Hao Y-B, Dun Y, and Yang S-P. (2001). Role of endogenous opioid peptides in protection of ischemic preconditioning in rat small intestine. Life sciences, 68: 1013-19.

Zöllner N, and Kirsch K. (1962). Colorimetric method for determination of total lipids. Fur Gesampte Exp Med, 135: 545-51 